\title{
Preparation of Reproducible Alkaline Phosphatase-Antibody Conjugates for Enzyme Immunoassay Using a Heterobifunctional Linking Agent
}

\author{
Antoinette Jeanson, JeAn-Michel Cloes, Mireille Bouchet, And Bernard RentieR* \\ Monoclonal Antibody Production Unit, General Biology Department, and* Fundamental Virology and \\ Immunology Unit, Microbiology Department, University ojLiège, Belgium
}

\begin{abstract}
Conjugates of alkaline phosphatase (AP) and mouse monoclonal immunoglobulins G (IgG) were prepared by means of the heterobifunctional linker, $N$-succinimidyl 3-(2-pyridyldithio)-propionate. The efficiency of such conjugates can be improved by optimizing the degree of substitution of IgG and AP. We have determined conditions yielding better performing conjugates than those synthesized by methods described previously. Moreover, the results obtained with the technique presented here are quite reproducible with all four monoclonal antibodies tested.
\end{abstract}

Key words: immunochemical methods - phosphatase - immunoglobulins - enzyme-antibody conjugation heterobifunctional linker - enzyme immunoassays.

Numerous methods have been used to prepare enzyme-antibody conjugates but very few have been applied to the production of alkaline phosphatase (AP) ${ }^{1}$-antibody conjugates, although AP is one of the most widely used markers for enzyme immunoassays (EIA). A procedure using sodium periodate has been described for conjugating alkaline phosphatase to human placental lactogen (1). According to this author, such a conjugate was better performing than conjugates synthesized by using glutaraldehyde or water-soluble carbodiimide.

Procedures using glutaraldehyde have been described (2,3). Such conjugates have been characterized with respect to their sizes and their immunoenzymatic properties (4), demonstrating that the quality of AP-antibody conjugates could not be improved by varying the glutaraldehyde concentrations.

We thought that the problem could be solved by using a technique where the reaction can be better controlled. The use of a het-erobifunctional reagent such as $N$-succini-midyl 3-(2-pyridyldithio)propionate (SPDP) has been described for horseradish peroxi-dase-antibody conjugation (5) and these conjugates have proven more efficient than those made with glutaraldehyde (6). Since the only requirement for this method is the presence of amino groups on both molecules, we explored it for AP-antibody conjugation.

The principle of SPDP conjugation is to substitute proteins with 2-pyridyl disulfide moieties. One of the proteins is then treated with a reducing agent to expose thiol groups on the added moieties. Both proteins can then be bound by the initiation of a chemical reaction between a 2-pyridyl disulfide moiety on one protein and the exposed aliphatic thiol on the other (6). By varying the SPDP protein and the protein 1/protein 2 ratios, the efficiency of the conjugates can be improved. This constitutes the first part of the present study. In the second part, SPDP, glutaralde-hyde, and periodate conjugates are compared in terms of efficiency.

\section{MATERIALS AND METHODS}

\section{Proteins}

The following mouse monoclonal antibodies against human immunoglobulins, prepared in our laboratory and purified on Protein A-Sepharose, were used: IgGl 43.6.C9 anti-human IgG; IgGl 74.8.B10 anti-human IgA; IgG2a 3F9.B8.E3 anti-human idiotype (MET); and IgG2b L5.F2.C3.G3 anti-human IgA.

Alkaline phosphatase from calf intestine "for enzyme immunoassay," batch No. 10695624-59, was from Boehringer GmbH (Mannheim, FRG).

Human IgG, IgA, and IgG3 (MET) were a gift from the Blood Transfusion Center (Liège, Belgium).

\footnotetext{
${ }^{1}$ Abbreviations used: AP, alkaline phosphatase; EIA, enzyme immunoassay; SPDP, $N$-succinimidyl 3-(2-pyri-dyldithio)propionate; IgG, immunoglobulin G; IgA, immunoglobulin A; DTT, dithiothreitol; FDNB, fluoio-dinitrobenzene; PB, phosphate buffer.
} 


\section{Chemicals}

SPDP was from Pharmacia, Sweden; di-thiothreitol (DTT) was from Boehringer GmbH; glutaraldehyde (EM grade, $25 \%$ aqueous solution) was from Taab Laboratories, UK; sodium periodate, fluorodinitro-benzene (FDNB) and ethylene glycol were from UCB, Belgium, monoethanolamine was from Merck, FRG, and $p$ nitrophenyl phosphate in tablets was from Sigma (St. Louis, MO).

\section{Conjugation Procedures}

1, SPDP. This was done according to Carlsson et al. (5) for the conjugation of horseradish peroxidase to immunoglobulins.

IgG and AP, dialyzed against sodium phosphate buffer $(0.1 \mathrm{M}, \mathrm{pH} 7.5)$ containing $\mathrm{NaCl}(0.1 \mathrm{M})$ were treated separately with SPDP (20 mM in absolute ethanol) up to the levels shown in Table 1 . The reactions were allowed to take place for $30 \mathrm{~min}$ at $20-23^{\circ} \mathrm{C}$. Excess SPDP and released $N$-hydroxysuccinimide were then removed by dialysis against sodium phosphate buffer $(0.1 \mathrm{M}, \mathrm{pH} 7.5)$ containing $\mathrm{NaCl}(0.1 \mathrm{M})$ for $\mathrm{IgG}$ and against sodium acetate buffer $(0.1 \mathrm{M}, \mathrm{pH} 4.5)$ containing $\mathrm{NaCl}(0.1 \mathrm{M})$ for AP. Dithiothreitol was added to AP transferred to sodium acetate buffer $(0.1 \mathrm{M}, \mathrm{pH} 4.5)$ containing $\mathrm{NaCl}(0.1 \mathrm{M})$, to a final concentration of $25 \mathrm{mM}$. After $20 \mathrm{~min}$ at $20-23^{\circ} \mathrm{C}$, excess DTT and released pyridine-2-thione were removed by gel filtration on Sephadex G-25 using sodium phosphate buffer $(0.1 \mathrm{M}, \mathrm{pH} 7.5)$ containing $\mathrm{NaCl}(0.1 \mathrm{M})$. Modified IgG and AP were mixed in the proportions shown in Table 1 and left for $20 \mathrm{~h}$ at $20-23^{\circ} \mathrm{C}$. The conjugates were then dialyzed against Tris$\mathrm{HCl}$ buffer $(0.05 \mathrm{M}, \mathrm{pH} 8)$.

\section{Glutaraldehyde, Both one-step and two-step procedures have been used.}

For the one-step method (2), $3 \mathrm{mg}$ of AP and $1 \mathrm{mg}$ of $\mathrm{IgG}$ were mixed together and dia-lyzed against phosphate buffer (PB, 0.1 M, pH 6.8). After the volume was adjusted to $1 \mathrm{ml}$ with $\mathrm{PB}, 0.008 \mathrm{ml}$ of $25 \%$ glutaraldehyde solution was added. The mixture was stirred for $2 \mathrm{~h}$ at $24^{\circ} \mathrm{C}$. Excess glutaraldehyde was removed by subsequent dialysis against phosphate-buffered saline and then against Tris- $\mathrm{HCl}$ buffer $(0.05 \mathrm{M}, \mathrm{pH} 8)$ at $4^{\circ} \mathrm{C}$.

The two-step procedure was performed as recommended by Boehringer GMBH in its user's notice: $3.5 \mathrm{mg}$ of AP in a $0.35-\mathrm{ml}$ volume, added with $1.2 \mathrm{ml}$ of potassium phosphate buffer $(0.05 \mathrm{M}, \mathrm{pH} 7.2)$, was treated with 0.01 $\mathrm{ml}$ of $25 \%$ glutaraldehyde solution. After incubation for $50 \mathrm{~min}$ at $24^{\circ} \mathrm{C}, 1.5 \mathrm{mg}$ of $\mathrm{IgG}$ in potassium phosphate buffer was added. The mixture was gently stirred for $75 \mathrm{~min}$ at $24^{\circ} \mathrm{C}$ and then dialyzed against Tris-HC1 buffer (0.05 M,pH 8).

\section{TABLE 1}

\begin{tabular}{ccc}
\multicolumn{3}{c}{$\begin{array}{c}\text { SPDP LEVELS AND COUPLING RATIOS OF AP-IgGl } \\
\text { 43.6.C9 CONJUGATES (mol SPDP/mol IgG }=3)\end{array}$} \\
\hline Conjugate & $\begin{array}{c}\text { mol SPDP/mol } \\
\text { AP }\end{array}$ & $\begin{array}{c}\text { AP/gG molar } \\
\text { ratio }\end{array}$ \\
\hline 1 & 4 & 1 \\
2 & 8 & 1 \\
3 & 8 & 1.5 \\
4 & 16 & 1 \\
5 & 16 & 1.5 \\
6 & 30 & 1 \\
7 & 30 & 0.5 \\
8 & 60 & 1 \\
9 & 60 & 0,5
\end{tabular}

3. Periodate. This procedure was derived from the method described by Williams (1) to conjugate AP to human placental lactogen. To $2 \mathrm{mg}$ of AP dissolved in $0.2 \mathrm{ml}$ of sodium hydrogen carbonate $(0.3 \mathrm{M}, \mathrm{pH} 8.1)$, we added $0.02 \mathrm{ml}$ of a $1 \%$ ethanolic solution of FDNB. The mixture was stirred gently for $2 \mathrm{~h}$ at $23^{\circ} \mathrm{C}$. Sodium periodate $(0.2 \mathrm{ml}, 0.05 \mathrm{M}$ in distilled water $\mathrm{pH} 6.5)$ was added. After gentle stirring for $6 \mathrm{~h}$ at $23^{\circ} \mathrm{C}$, ethylene glycol $(0.02$ $\mathrm{ml}, 0.16 \mathrm{M}$ in distilled water $\mathrm{pH} 6.5$ ) was added, and the mixture was stirred gently for $1 \mathrm{~h}$ at $23^{\circ} \mathrm{C}$, before dialysis for $18 \mathrm{~h}$ against 1 liter of carbonate buffer $(0.01 \mathrm{M}, \mathrm{pH} 9.5)$. To the dialysate, either 3 or $0.75 \mathrm{mg}$ of $\mathrm{IgG}$ in 0.2 or $0.05 \mathrm{ml}$ of carbonate buffer $(0.01 \mathrm{M}, \mathrm{pH} 9.5)$ was added. Molar ratios were respectively 1 and 4 . The mixture was stirred gently for $24 \mathrm{~h}$ at $4^{\circ} \mathrm{C}$. Monoethanolamine $(0.04 \mathrm{ml}, 2 \mathrm{M}, \mathrm{pH} 9.5)$ was added and the conjugate was finally dialyzed against 2 liters of Tris- $\mathrm{HCl}$ buffer $(0.05 \mathrm{M}, \mathrm{pH} 8)$. 


\section{Enzyme Immunoassay}

EIAs were carried out in 96-well mi-croplates (Nunc 4-39454.96F) using a technique derived from that of Voller and Bidwell (7). In order to compare the enzyme activities of the conjugates, the plates were coated overnight at $4^{\circ} \mathrm{C}$ with $50 \mathrm{ng}$ per well of antigens diluted in sodium carbonate-bicarbonate buffer $(0.05 \mathrm{M}, \mathrm{pH} 9.6)$, containing $0.02 \%(\mathrm{w} \mathrm{v}) \mathrm{NaN}_{3}$. Wells were washed twice with running water and then saturated for 45 min at $20-23^{\circ} \mathrm{C}$, with phosphate buffer $(20 \mathrm{mM}$, pH 7.5) containing $0.15 \mathrm{M} \mathrm{NaCl}, 2 \%$ ovalbumin, and $0.05 \%$ (v/v) Tween 20 . Serial dilutions of conjugates were then added in $0.05-\mathrm{ml}$ volumes and incubated for $1 \mathrm{~h}$ at $37^{\circ} \mathrm{C}$. After five more washings with running water, the substrate $p$-nitrophenyl phosphate (one $5-\mathrm{mg}$ tablet $/ 5 \mathrm{ml}$, diluted in diethanolamine buffer, $1 \mathrm{M}$, pH 9.8) was added in $0.05-\mathrm{ml}$ volumes. After a 30 -min incubation at $37^{\circ} \mathrm{C}$, wells were supplemented with $0.15 \mathrm{ml} 0.4 \mathrm{~N} \mathrm{NaOH}$. Ab-sorbances were measured at $405 \mathrm{~nm}$ in a Ti-tertek Multiscan spectrophotometer (Flow Labs, France).

\section{RESULTS AND DISCUSSION}

\section{Adaptation of the SPDP Method to AP-IgG Conjugation}

The conjugates listed in Table 1 have been compared by direct EIA. Their activities are expressed by the concentrations of AP and IgG required to reach a fixed OD value of 0.4. We felt entitled to do so since the AP we used was from a single homogenous batch and all experiments were carried out in parallel, with the same specific activity of AP.

Three parameters can be monitored during the conjugation process: the SPDP/AP, the SPDP/IgG, and the AP/IgG molar ratios.

From our results (Fig. 1), it appears that the higher the SPDP/AP molar ratio, the more efficient the conjugate. However, ratios higher than 60 have not been tested and might prove still more efficient. An optimal $\mathrm{SPDP} / \mathrm{rabbit} \mathrm{IgG}$ molar ratio has been found earlier to be between 2.5 and 3.5 (5). For this reason, we have not tested this variable and used a fixed value of 3. Since we worked with mouse monoclonal IgGs, this SPDP/IgG ratio could well be slightly different for each antibody and perhaps be refined further. We have tested pairs of conditions for the AP/IgG ratio (0.5 and 1; 1 and 1.5) and found that the value of 1 was always better.

FIG. 1, Activity of AP conjugates listed in Table 1, at an OD value of 0.4, Conjugate No. 1 is not represented because its EIA curve does not reach an OD of 0.4. Conjugate No. 2, $\Delta ; 3, A ; 4, O ; 5, ; 6, \quad ; 7, \quad ; 8,+; 9, X$.

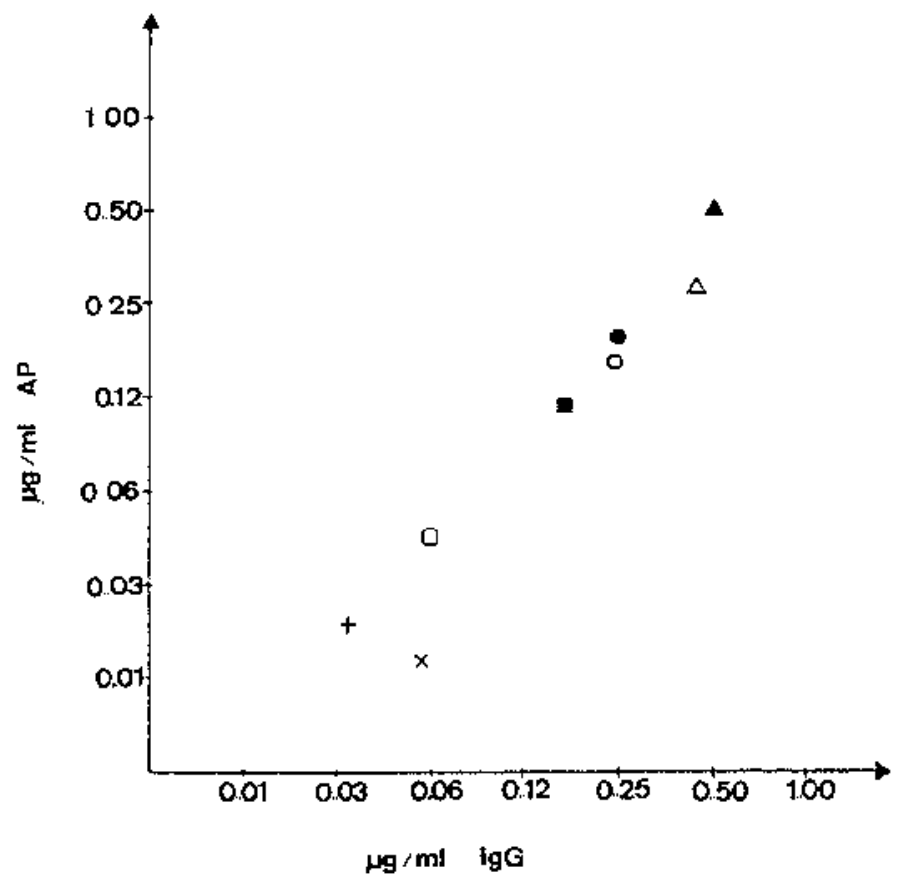


FIG. 2. Activity of IgGl 43.6.C9 (a), IgGl 74.8.B10 (b), IgG2a 3.F9.B8.E3 (c), and IgG2b L5.F2.C3.G3 (d)—AP conjugates,. $\triangle$ SPDP; O, periodate, $1: 1 ;$, peiiodate, $4: 1 ;$, glutaraldehyde, one step; , glutaral-dehyde, two step.
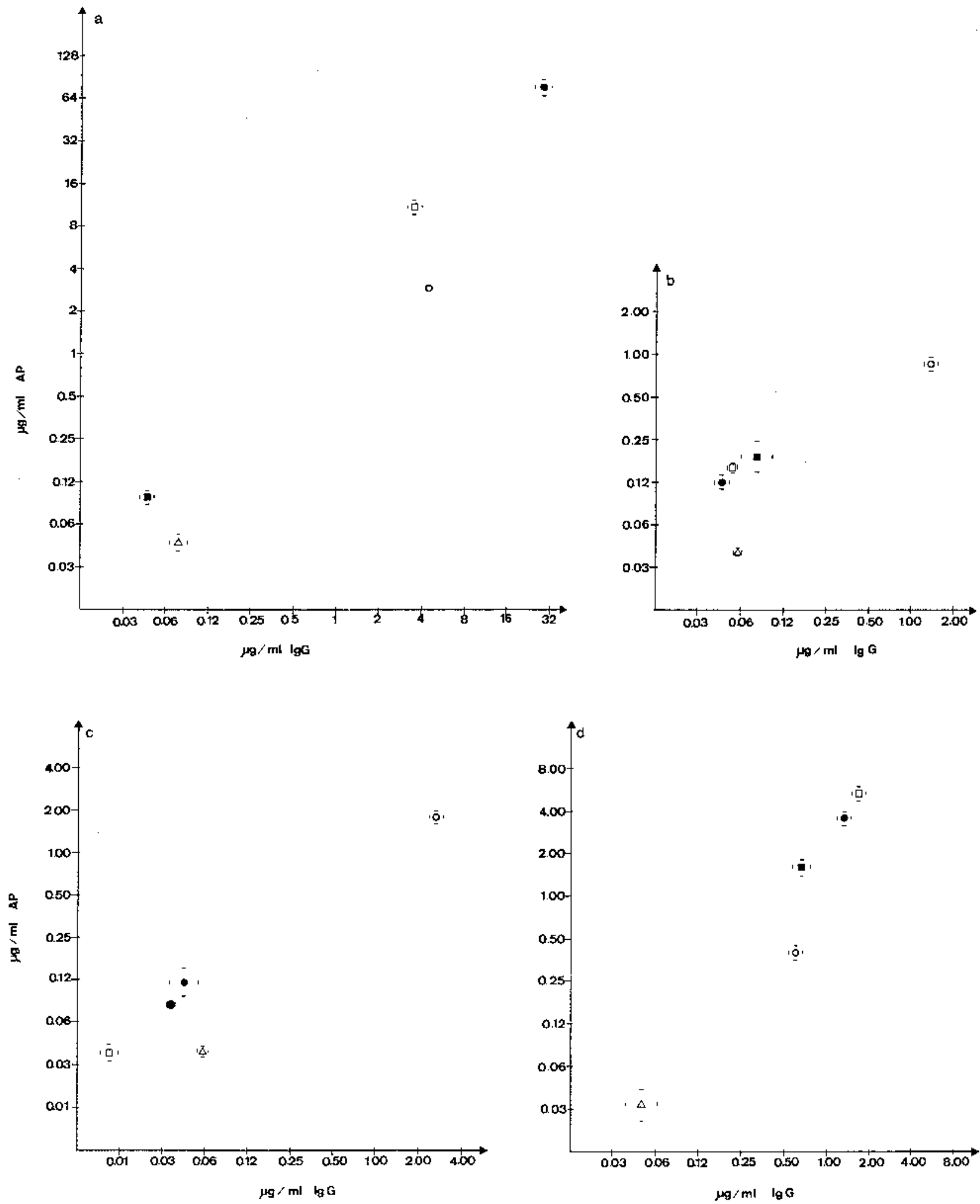

In our experiments, and with the particular mouse monoclonal antibody IgGl 43.6.C9, conjugate No. 8 (60 mol $\mathrm{SPDP} / \mathrm{mol} \mathrm{AP} ; 3 \mathrm{~mol} \mathrm{SPDP} / \mathrm{mol} \mathrm{IgG} ; \mathrm{AP} / \mathrm{IgG}$ molar ratio = 1) has been considered the best performing. 


\section{Reproducibility of the SPDP Method and Comparison with Glutaraldehyde and Periodate Techniques}

The conditions used for preparation of conjugate No. 8 (IgGl 43.6.C9) were selected to couple three other antibodies to AP: IgG1 74.8.B10, IgG2a 3F9.B8.E3, and IgG2b L5.F2.C3.G3, belonging to different isotypes or displaying different specificities. In addition, these four monoclonal antibodies were each coupled by both the one-step and the two-step glutaraldehyde and periodate procedures. The observations obtained from EIA are shown in Figs. 2a-2d, where the activities are expressed by the AP and IgG initial concentrations required to reach a fixed OD value of 0.6. For all antibodies tested, the SPDP procedure does not always yield the most efficient conjugates, but when it is not the case, the difference between the SPDP conjugate and the most efficient one is not significant. Moreover, the SPDP technique seems to be very reproducible from one antibody to another: the AP and IgG concentrations at which the different SPDP conjugates show an OD of 0.6 are similar, as opposed to what is observed with the periodate and both one-step and two-step glutaraldehyde procedures. The lack of reproducibility of the latter methods could be explained by the fact that glutaraldehyde and periodate conjugates are likely to contain a wide range of enzyme-IgG complexes as well as of enzymeenzyme and IgG-IgG homopolymers, while the SPDP procedure avoids homopolymerization and intramolecular crosslinking $(7,8)$.

In conclusion, the use of a heterobifunc-tional linking agent to prepare alkaline phos-phatase-antibody conjugates presents striking advantages over techniques based on homobifunctional linkers: efficiency and reproducibility. By testing systematically a broad range of coupling conditions, we have characterized the most efficient one: $60 \mathrm{~mol}$ of SPDP/mol of AP, $3 \mathrm{~mol}$ of SPDP/mol of IgG, and an AP to IgG molar ratio of 1.

\section{Acknowledgments:}

We thank C. Meunier for her skillful help and Dr. D. Sondag for providing us with antigens. This work was performed under Contract PREST/ULg/12 and a contract of "Actions Concertées" with the Belgian Prime Ministry Services (Programmation de la Politique Scien-tifique) and with the help of the FNRS of Belgium., Scientific responsibility for this text is taken fully by the authors.

\section{REFERENCES}

1. Williams, D. G. (1984) J Immunol Methods 72, 261 -268.

2. Engvall, E,, and Perlmann, P, (1971)Immunochemistry 8, 871-874.

3. Kearney, J. F., Radbruch, A., Liesegang, B., and Rajewsky, K. (1979) J. Immunol 123, 1548-1550,.

4. Ford, D. J., Radin, R., and Pesce, A. J. (1978) Immunochemistry 15, 237-243.

5. Carlsson, J., Drevin, H., and Axén, R. (1978) Biochem J. 173, 723-737.

6. Nilsson, P., Bergquist, N. R., and Grundy, M. S. (1981) J Immunol Methods 41, 81-93.

7. Voller, A., and Bidwell, D, E. (1975) Brit J Exp Pathol 56, 338-345.,

8. Pain, D., and Surolia, A. (1981) J Immunol Methods 40, 219-230. 